\title{
$\mathrm{Ni}$ 添加 $\mathrm{SiC}$ 焼結体の電気伝導度
}

\author{
岡野一雄・桜井悟 $\cdot$ 加藤 恭正 \\ (小山職業訓練短期大学校電子技術科, 323 栃木県小山市横倉三竹 612-1)
}

\section{Electrical Conductivity of Sintered SiC Containing Ni}

\author{
Kazuo OKANO, Satoru SAKURAI and Yasumasa KATOU \\ $\left(\begin{array}{l}\text { Department of Electronic Devices Technology, Oyama Vocational Training College, } \\ 612-1 \text {, Yokokura Mitake, Oyama-shi, Tochigi }\end{array}\right.$
}

The effects of $\mathrm{Ni}$ addition on the microstructure and the electrical conductivity of silicon carbide ( $\mathrm{SiC}$ ) ceramics were investigated. The SiC ceramics containing more than $1.0 \mathrm{wt} \% \mathrm{Ni}$ were porous regardless of the sintering temperature, while the specimens containing less than $0.5 \mathrm{wt} \% \mathrm{Ni}$ and sintered at above $2050^{\circ} \mathrm{C}$ showed high densities ( $>98 \%$ of theoretical). The electrical conductivity at $300 \mathrm{~K}$ of these dense SiC ceramics increased from $5 \times 10^{-5}$ to $1 \times 10^{-3} \mathrm{~S} / \mathrm{m}$ with $\mathrm{Ni}$ addition from 0 wt\% to 0.5 wt\%.

[Received May 25, 1989 ; Accepted July 14, 1989]

Key-words : Electrical conductivity, Sintered SiC, Ni addition, SEM observation, Microstructure

\section{1. 緒 言}

非酸化物系セラミックスとして代表的な $\mathrm{SiC}$ 焼結体 は, 高温安定性に優れたセラミックス半導体であり, 高 温用サーミス夕等の電子素子への応用が期待されてい る $^{1,2)} . \mathrm{SiC}$ 焼結体の電気物性はその製造条件, 特に半 導体であるために焼結体に含まれる不純物の種類, 濃度 に大きく依存する3). そこで, $\mathrm{SiC}$ 焼結体の製造条件と して焼成温度及び Ni (ニッケル) の添加量を選び, Ni の添加量により $\mathrm{SiC}$ 焼結体の電気伝導度を制御するこ とを試みた。

\section{2. 実 験}

平均粒径 $0.42 \mu \mathrm{m}$ の昭和電工製 $\alpha-\mathrm{SiC} に$, 焼結助 㓲として炭素と炭化ホウ素をそれぞれ $2.0 \mathrm{wt} \%, 0.625$ wt\% 添加し, 更に Ni を0 3.0 wt\% 添加した。この混 合粉体をボールミルで 24 時間湿式混合した。混合後, 乾燥して得られた粉体を $300 \mathrm{MPa}$ で一軸加圧成形を行 い, ペレット状の成形体とした。この成形体を黒鉛抵抗 炉を用いて焼成温度 $1950^{\circ} \sim 2100^{\circ} \mathrm{C}, 30$ 分, 真空中で焼 成した. 焼成後, 得られた試料の表面を研削し, 電極亡 してアルミニウムを真空蒸着したものを電気伝導度測定 用の試料とした.これらの試料に直流バイアスを印加し, 四端子法により真空中にて $300 \mathrm{~K}$ で測定を行った.

\section{3. 結果と考察}

焼成温度と電気伝導度の関係を図 1 に示す。この図に おいて, $1950^{\circ} \mathrm{C}$ で焼成した試料の電気伝導度は $\mathrm{Ni}$ の添 加量に無関係に $1 \mathrm{~S} / \mathrm{m}$ 程度である. 一方, $2000^{\circ} \mathrm{C}$ 以上 で焼成した試料の電気伝導度は, Ni の添加量が増加す
るに従って高くなっている. Ni の添加量が 0 及び 0.1 $\mathrm{wt} \%$ の試料は, 焼成温度が $1950^{\circ} \sim 2000^{\circ} \mathrm{C}$ の範囲にお いて著しい電気伝導度の減少を示し, 焼成温度 $2050^{\circ} \mathrm{C}$ 以上においては電気伝導度が若干増加する傾向を示して いる. Ni の添加量が $0.2 \mathrm{wt} \%, 0.5 \mathrm{wt} \%$ の試料の電気 伝導度は, 焼成温度 $1950^{\circ} \sim 2000^{\circ} \mathrm{C}$ において著しく減少 し， $2000^{\circ} \mathrm{C}$ 以上の焼成温度において飽和する傾向を示

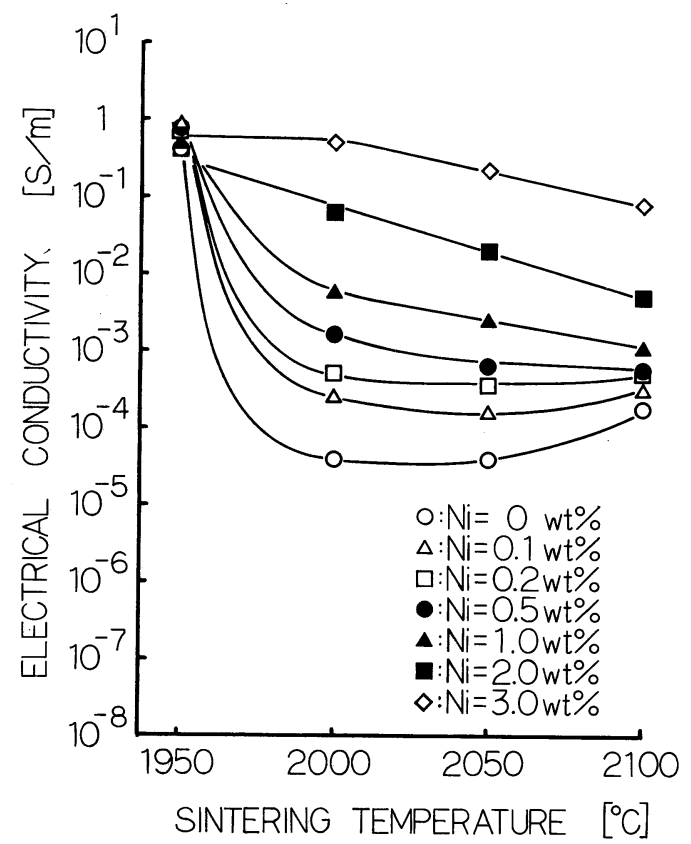

Fig. 1. Electrical conductivity at $300 \mathrm{~K}$ of sintered $\mathrm{SiC}$ as a function of sintering temperature and $\mathrm{Ni}$ content. 


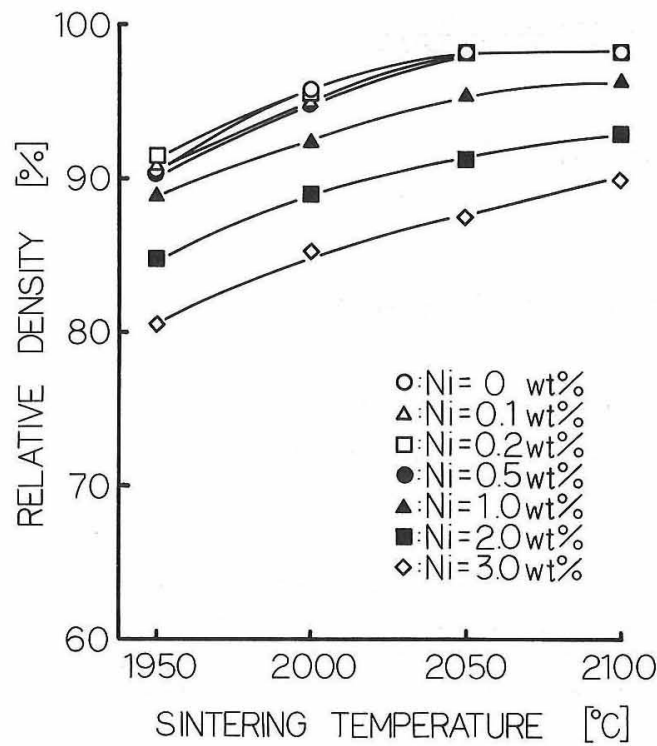

Fig. 2. Relative density of sintered $\mathrm{SiC}$ as a function of $\mathrm{Ni}$ content.
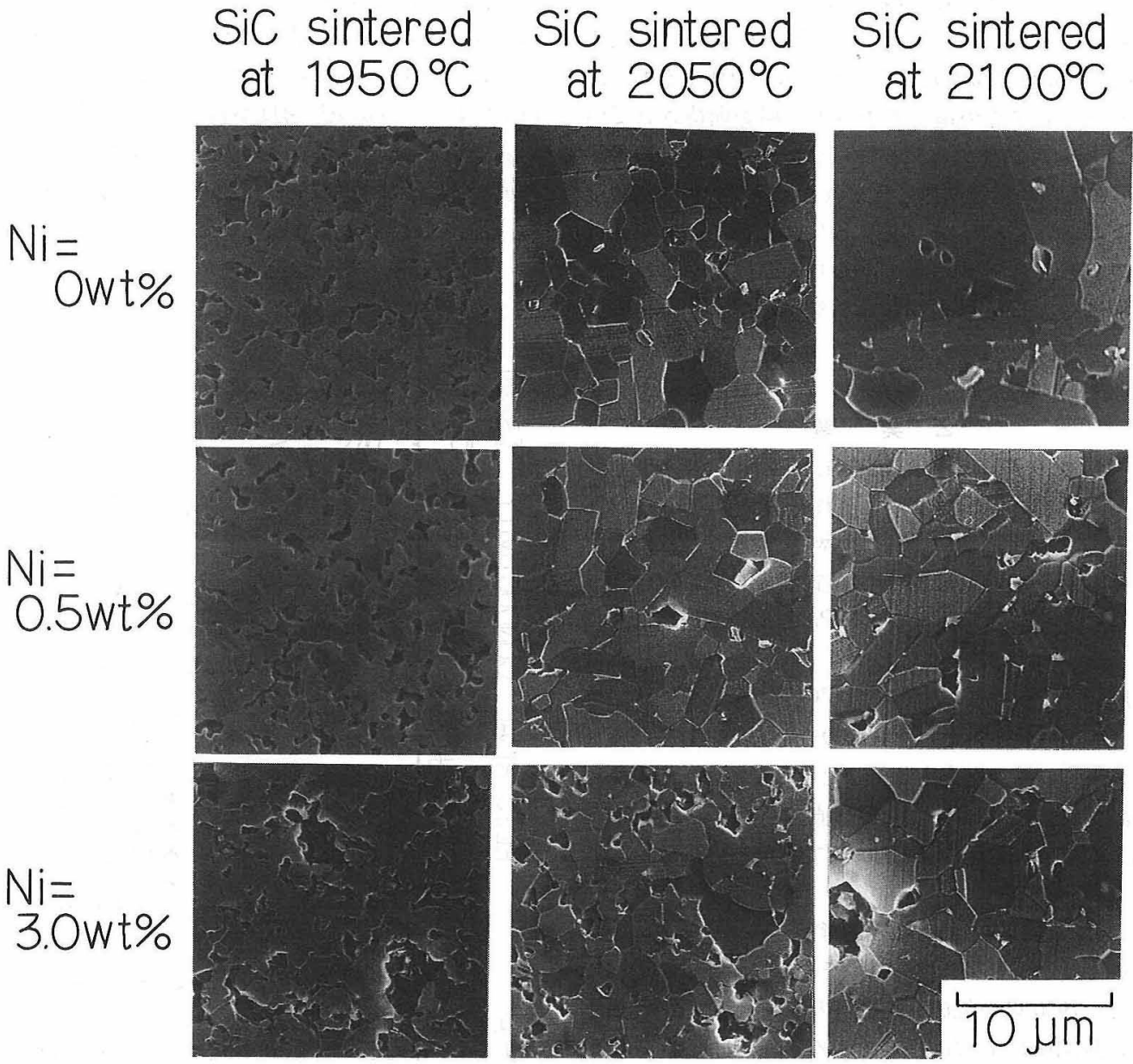

Fig. 3. SEM photographs of etched surface of sintered SiC. 
に無関係であるが， 0.5 wt\% 以上においては Ni の添加 量が大きいほど低くなっている.

図 3 に Ni の添加量を 0, 0.5,3.0 wt\% として $1950^{\circ}$, $2050^{\circ}, 2100^{\circ} \mathrm{C}$ で焼成した試料の走查型電子顕微鏡 (SEM) 写真を示す．この図より，焼成温度が上昇す るに従って粒成長していることが確認できる. また, $\mathrm{Ni}$ の添加量が増加するに従って気孔の占める割合が大 きくなることがわかる. $1950^{\circ} \mathrm{C}$ で焼成した試料は $\mathrm{Ni}$ の 添加量に関係なく気孔の占める割合が大きく，いずれの 試料も粒径は $2 \mu \mathrm{m}$ 程度である. $2050^{\circ} \mathrm{C}$ で焼成した試 料の微構造は, $\mathrm{Ni}$ の添加量が $0,0.5 \mathrm{wt} \%$ の場合, 気孔 の占める割合が小さく, ち密化していることが確認でき, いずれの試料でも粒径は $5 \mu \mathrm{m}$ 程度である. Ni の添加 量が $3.0 \mathrm{wt} \%$ の試料は気孔の占める割合が大きく，粒 径が小さいことが確認できる. $\mathrm{Ni}$ を添加しないで $2100^{\circ} \mathrm{C}$ で焼成した試料では異常粒成長が認められるが, $\mathrm{Ni}$ を添加した試料では異常粒成長が認められなかった。 また, Ni の添加量が 3.0 wt\% の試料においては粒径が 小さく, 気孔の占める割合が大きかった.このように, $\mathrm{Ni}$ を添加することにより $\mathrm{SiC}$ 焼結体の粒成長は制御さ
れることが明らかになった。

\section{4. 総 括}

以上の実験結果より, $\mathrm{SiC}$ 焼結体の電気伝導度に及 ぼす $\mathrm{Ni}$ の効果は次のようにまとめられる.

（1） $\mathrm{SiC}$ に添加した $\mathrm{Ni}$ は焼成過程において，粒成 長を阻害し, Ni の添加量が 1.0 wt\% 以上の場合にはこ の効果が顕著であった。しかし， Ni の添加量が 0.5 $\mathrm{wt} \%$ 以下の場合には, 焼成温度 $2050^{\circ} \mathrm{C}$ 以上において相 対密度は $98 \%$ 程度であった.

（2） $\mathrm{SiC}$ 焼結体の電気伝導度は $\mathrm{Ni}$ の添加量を増加 すると大きくなる傾向を示した．また，試料の密度が $98 \%$ 程度にち密化した試料, すなわち, Ni の添加量を $0 \sim 0.5 \mathrm{wt} \%$ として $2050^{\circ} \mathrm{C}$ 以上で焼成した試料の電気 伝導度は, $5 \times 10^{-5} \sim 1 \times 10^{-3} \mathrm{~S} / \mathrm{m}$ の範囲で制御できた.

\section{文 献}

1) C. van Opdorp and J. Vrakking, J. Appl. Phys., 40, 2320-22 (1964).

2）岡野一雄, 窯協, 94, 219-25 (1986).

3）岡野一雄, 飯田治久, 表面科学, 9, 362-67 (1988). 